\title{
Pipemidic Acid
}

National Cancer Institute

\section{Source}

National Cancer Institute. Pipemidic Acid. NCI Thesaurus. Code C66394.

A pyridopyrimidine antibiotic derivative of piromidic acid with activity ag ainst gramneg ative bacteria, as well as some gram-positive bacteria. Pipemidic acid exhibits greater activity than piromidic acid or nalidixic acid and shows moderate activity against bacteria that are resistant to piromidic acid and nalidixic acid. 